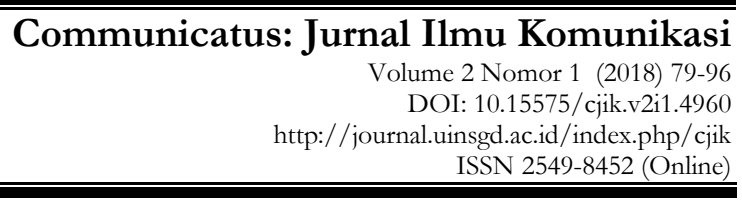

\title{
Independensi Wartawan PWI Jawa Barat dalam Berita Keislaman
}

\author{
Lisna Novita ${ }^{1 *}$ \\ ${ }^{1}$ Sekretariat DPRD Provinsi Jawa Barat \\ *email.lisnanovita29@gmail.com
}

\begin{abstract}
$A B S T R A C T$
This study aims to interpret the understanding of PWI West Java journalists on the concept of independence in the news, describe constructing a reality into a story, and describe the Islamic interpretation of West Java PWI journalists on Islamic news. This research is qualitative research using phenomenological methods. Data collection techniques used in this study are observation, interview and documentation techniques. The results of this study indicate that West Java PWI journalists are very understanding and important to the concept of independence but are flexible when the construction process of Islamic news is discussed, because the construction of the reporting of West Java PWI journalists is still carried out on the basis of media pressure.
\end{abstract}

Keywords: independence; reporter; and PWI West Java

\begin{abstract}
ABSTRAK
Penelitian ini bertujuan untuk menginterpretasikan pemahaman wartawan terhadap konsep independensi dalam pemberitaan, mendeskripsikan konstruksi sebuah realitas menjadi sebuah berita, dan interpretasi keislaman wartawan PWI (Persatuan Wartawan Indonesia) Jawa Barat terhadap berita keislaman. Penelitian ini menggunaan jenis penelitian kualitatif dengan metode fenomenologi. Teknik pengumpulan data dalam penelitian ini adalah teknik observasi, wawancara dan dokumentasi. Hasil penelitian menunjukan bahwa wartawan PWI Jawa Barat sangat memahami dan memandanag penting terhadap konsep independensi namun bersifat fleksibel saat proses konstruksi berita keislaman di laangan, karena konstruksi pemberitaan wartawan PWI Jawa Barat masih dilakukan atas dasar ketingan media.
\end{abstract}

Kata Kunci : Independensi; wartawan; PWI Jawa Barat

\section{PENDAHULUAN}

Pemberitaan keislaman di media telah melahirkan dua hal, Pertama, pemberitaan tentang aksi-aksi keislaman di media menghadirkan fenomena baru, yaitu lahirnya stigma buruk tentang Islam, karena fenomena yang tengah terjadi adalah maraknya pemberitaan mengenai Islam radikal dan Islam teroris. Berita- 
Lisna Novita

berita mengenai Islam tidak selaras dengan fakta. Berita yang tidak berimbang memicu banyaknya pembelaan dari umat Islam. Berita bohong atau hoax yang diberitakan di media menimbulkan berbagai macam perpecahan. Berita hoax menjadikan semua berubah menjadi tuduhan yang merusak. Berita bohong justru menyulap perbedaan perselisihan (ikhtilaf) menjadi perpecahan (iftiraq).

Fenomena yang sering disebut sebagai konvergensi media ini memunculkan beberapa kemajuan penting (Dulwahab, 2010: 23). Maggie Gallengher (dalam Kovach dan Rosantiel, 2001:121) berpendapat, wartawan berkomitmen pada kebenaran. Langkah penting dalam pengejaran kebanaran dan memberi informasi kepada warga bukanlah netralitas melainkan independensi. Independensi juga berarti bahwa wartawan tidak dapat ditekan oleh campur tangan dari pihak mana pun, termasuk dari pemilik perusahaan media itu sendiri. Seorang wartawan dalam aktivitas jurnalistik dintuntut menghadirkan kebenaran sebagai tujuan dari pekerjaannya. Mulai dari memilih narasumber, wawancara hingga saat menuliskannya sebagai berita.

Jurnalistik adalah kegiatan yang memungkinkan pers atau media massa bekerja dan diakui eksistensinya dengan baik (Sumadiria, 2008:2). Menurut Effendy dalam Sumadiria, secara sederhana jurnalistik dapat didefinisikan sebagai teknik mengelola berita mulai dari mendapatkan bahan sampai kepada menyebarluaskannya kepada masyarakat. Sedangkan Djen Amar dalam mengatakan bahwa jurnalistik adalah kegiatan mengumpulkan, mengolah, dan menyebarkan berita kepada khalayak seluas-luasnya dengan secepat-cepatnya (Sumadiria, 2008:3).

Berita diartikan sebagai laporan tercepat mengenai fakta dan opini yang menarik atau penting, bagi sejumlah besar penduduk (Michael V. Chamley dalam Assegaf, 1983:23-24). Sedangkan menurut Dean M. Lyle Spencer dalam Assegaf (1983: 23) menyatakan bahwa berita merupakan suatu kenyataan atau ide yang benar yang dapat menarik perhatian sebagaian besar pembaca. Sedangkan berita mengenai keislaman tersendiri merupakan segala bentuk pemberitaan seputar dunia Islam, meliputi segala fenomena yang terjadi dalam ranah sosial, politik, budaya, ekonomi, dan pendidikan.

Sejalan dengan fenomena ini, independensi wartawan sangat dibutuhkan untuk menjamin kualitas berita keislaman. Terjaminnya independensi wartawan, secara tidak langsung berdampak pada independensinya dalam membuat sebuah berita. Independensi menurut Kamus Besar Bahasa Indonesia (KBBI) adalah keadaan yang tidak bergantung kepada orang lain, keadaan merdeka, dan tidak terikat. Bill Kovach dan Tom Rosenstiel menyebutkan ada sembilan elemen jurnalisme, pada elemen keempat disebutkan, jurnalis harus tetap independen dari pihak yang mereka liput (Kovach, 2006: 119).

Profesi wartawan saat kini berkembang sangat pesat, secara kualitas, mayoritas wartawan berlatar belakang pendidikan tinggi, bukan lagi tamatan 
Independensi Wartawan PWI Jawa Barat dalam Berita Keislaman SMA, dan dengan kondisi ini bukan hanya lulusan fakultas ilmu komunikasi atau ilmu jurnalistik yang bisa menjadi seorang wartawan, lulusan ilmu pengetahuan lain pun bisa menjadi seorang wartawan tanpa melalui jenjang pendidikan jurnalistik yang memadai. Oleh karenanya tidak mengherankan jika terdapat wartawan menyalahgunakan profesinya dan melanggar kode etik jurnalistik.

Kode Etik Jurnalistik merupakan landasan moral profesi dan ramburambu atau kaidah penuntun sekaligus pemberi arah kepada wartawan tentang apa yang seharusnya dilakukan dan apa yang seharusnya dihindari dalam melaksanakan tugas-tugas jurnalistiknya (Zaenuddin, 2011: 67). Kode etik jurnalistik merupakan panduan penting karena dapat menjadi penentu proses jurnalistik. Seluruh pihak memiliki tanggung jawab moral untuk mengawal pelaksanaan kode etik jurnalistik, wartawan dan media massa sebagai pelaku jurnalistik memiliki peran besar dalam menentukan penerapan kode etik jurnalistik secara konsisten dan penuh komitmen yang pada akhirnya akan menghasilkan persepsi masyarakat tentang perilaku jurnalistik yang objektif dan profesional. Indikatornya akan terlihat dari penyajian berita yang memiliki kualitas tinggi.

Organisasi menurut Handayaningrat (1985: 42) adalah wadah (wahana) kegiatan daripada orang-orang yang bekerja sama dalam usahanya mencapai tujuan. Dalam wadah kegiatan tersebut, setiap orang harus jelas tugas, wewenang dan tanggungnjawabnya, hubungan dan tata kerjanya.

Handayaningrat (1985: 43) menjelaskan mengenai ciri-ciri organisasi sebagai berikut: 1) Adanya suatu kelompok orang yang dapat dikenal. 2) Adanya kegiatan yang berbeda-beda tetapi satu sama lain saling berkaitan (interdependent part) yang merupakan kesatuan usaha/kegiatan. 3) Tiap-tiap anggota memberikan sumbangan usahanya/tenaganya. 4) Adanya kewenangan, koordinasi, dan pengawasan. 5) Adanya suatu tujuan (the idea of goals). Sedangkan ciri-ciri organisasi menurut Hardjito (1997: 12) yaitu: 1) Adanya sekelompok orang. 2) Antar hubungan. 3) Kerja sama yang didasarkan atas hak, kewajiban, dan tanggung jawab masing-masing orang untuk mencapai tujuan.

Penelitian sebelumnya yang relevan dengan penelitian ini adalah yang pertama, mengkaji tentang profesionalisme wartawan (Wibawa, 2012). Hasil penelitian tentang implikasi uji kompetensi terhadap kesadaran hukum pers wartawan di kota Denpasar. Kedua, Penelitian tentang struktur dominasi media pada independensi wartawan (Mustofa, 2014). Penelitian lain, ketiga, yang juga berkaitan dengan independensi media (Darmanto, 2015), yang menekankan pentingnya independensi media di tengah hiruk pikuk perpolitikan di Indonesia. Keempat, penelitian lainnya mengatakan bahwa independensi media dan wartawan sulit untuk sepenuhnya bersikap independen, mengikat praktik bermedia, termasuk pemberitaan, tidak hadir dari ruang hampa (Musfialdy, 2019). Kelima, dengan menggunakan teori dari Theo van Leeuwen, menelisik 
Lisna Novita

bagaimana pemberitaan berita online dalam melakukan framing terhadap ormasormas Islam (Mujianto, 2015). Penelitian lainnya ditinjau dari perspektif ekonomi-politik media massa (Heryanto, 2017). Hasil penelitian menunjukkan bahwa perspektif ekonomi-politik media memandang bahwa media massa (koran, televisi, radio, dan sebagainya) tidak dapat dipandang bebas kepentingan, sebab pada dasarnya selalu merepresentasikan kepentingan-kepentingan tertentu (ekonomi, politik, budaya bahkan ideologi). Penelitian tentang jurnalistik foto berkaitan dengan penerapan kode etik jurnalistik foto (Berutu, 2012). Penelitian ini mencoba menganalisis bagaimana kode etik jurnalistik sebagai pedoman kerja wartawan di terapkan dalam pemberitaan di harian Kompas.

Penelitian ini berlokasi di kantor PWI Jawa Barat yang beralamat di Jalan Wartawan 2 No. 23, Turangga, Lengkong, Kota Bandung, Jawa Barat. Penelitian ini mengambil lokasi di kantor PWI jawa barat, karena PWI Jawa Barat dianggap sebagai satu-satunya institusi lembaga tempat berhimpunnya sejumlah wartawan yang cenderung sudah lama terbentuk, dan memiliki jumah keanggotaan yang relatif lebih besar dan lebih plural dibandingkan dengan yang lain.

Metode yang digunakan dalam penelitian ini adalah metode fenomenologi. Informan kunci (key informan) dalam penelitian ini adalah Mirza Zulhadi yang merupakan ketua umum PWI Jawa Barat. Adapun informan dalam penelitian ini adalah: 1) Wawan Ruswana, didasarkan atas jam terbang, dan masa berkerja di dunia kejurnalistikan yang sudah lama sehingga bisa dikategorikan sebagai wartawan senior. Wawan Rusmana juga merupakan wakil sekretaris umum PWI Jawa Barat. 2) Firman, dengan pertimbangan selain menjadi anggota PWI Jawa barat Firman merupakan redaktur Pikiran Rakyat, sehingga diasumsikan mengetahui kemampuan dari masing-masing wartawan. 3) Ridwan Mustofa yang merupakan anggota dari PWI Jawa Barat sekaligus wartawan media Kompas TV. Ridwan dipilih dengan pertimbangan wartawan yang memiliki pengalaman dalam membuat berita keislaman. Pemilihan informan tersebut berdasarkan pertimbangan bahwa memiliki data, dan bersedia memberikan infromasi yang lengkap serta akurat.

\section{HASIL DAN PEMBAHASAN}

PWI Cabang Jawa Barat, dibentuk pada 5 Februari 1950 tatkala sejumlah wartawan Bandung berkumpul di Jalan Dalem Kaum 52 (kantor surat kabar berbahasa Sunda Sipatahoeunan). Dilatarbelakangi oleh keinginan untuk merperkuat ikatan wartawan republieken dalam menghadapi pihak kolonial, mereka terpanggil untuk mendirikan PWI (yang secara nasional sudah terbentuk sejak tahun 1946) di daerah.

PWI beranggotakan wartawan yang tersebar di seluruh Indonesia. Salah satunya terdapat PWI Cabang Jawa Barat. PWI Cabang Jawa Barat berdiri pada 5 Pebruari 1950 ketika sejumlah wartawan Bandung berkumpul di Jalan Dalem 
Independensi Wartawan PWI Jawa Barat dalam Berita Keislaman

Kaum 52 (kantor surat kabar berbahasa Sunda Sipatahoeunan), dilatarbelakangi oleh keinginan untuk memperkuat ikatan wartawan republieken dalam menghadapi pihak kolonial. Mereka terpanggil untuk mendirikan PWI (yang secara nasional sudah terbentuk sejak tahun 1946) di daerah.

PWI cabang Jawa abrat ini dianggap menjadi barometer aktivitas jurnalistik di kancah nasional yang merupakan perkumpulan dari berbagai cabang media di Indonesia. Independensi merupakan konsep awal yang mendasari berita bersifat netral dan objektif. Maka untuk dapat mengetahui bagaimana objektivitas pemberitaan keislaman wartawan yang ada di PWI Jawa Barat penelitian ini memfokuskan penelitian kedalam tiga pembahasan yaitu tentang pemahaman wartawan terhadap independensi, interpretasi wartawan terhadap berita keislaman, dan konstruksi realita menjadi sebuah berita yang dilakukan oleh wartawan PWI Jawa Barat.

\section{Pemahaman Wartawan PWI Jawa Barat terhadap Independensi}

Dalam kajian hukum dan media massa, moral dan etika tersebut dikaitkan pada kewajiban para jurnalistik antara lain seperti; pelaksanaan kode etik jurnalistik dalam setiap aktivitas jurnalistiknya, tunduk pada institusi dan peraturan hukum untuk melaksanakan dengan etiket baiknya sebagaimana ketentuan-ketentuan di dalam hukum tersebut yang merupakan perangkat prinsip-prinsip dan aturanaturan yang pada umumnya sudah diterima dan disetujui oleh masyarakat. Sehubungan dengan hal itu, prinsip etika bagi profesi jurnalistik memberikan dasar hukum bagi pengelolaan pemberitaan di media secara tertib dalam hubungan antar subyek hukum (Dahlan, 2011: 396). Pers atau wartawan, meski memiliki kebebasan dalam menjalankan tugasnya telah dijamin oleh undangundang, tetapi memiliki batasan-batasan dan aturan-aturan yang mengatur agar kegiatannya tidak ada pihak yang merasa dirugikan, mengancam persatuan bangsa serta bertentangan dengan semangat dalam menegakan hak asasi manusia (HAM), karena bagaimanapun, wartawan atau pers harus tetap menjunjung tinggi norma yang berlaku dalam suatu masyarakat (Tatipang, 2013). Kebebasan pers merupakan hal yang fundamental karena tugas pers untuk menjadi pemantau kebijakan dalam masyarakat. Pers menjadi salah satu tonggak demokrasi. Di sisi yang lain pers juga harus bisa mempertanggungjawabkan pemberitaannya. Untuk ini, perlu penegakkan profesionalisme (Sulistyowati, 2006: 127).

Dalam pemberitaan dan pemberitaan tentang urgensi indepedensi itu, ketua dewan kehormatan PWI Pusat Ilham Bintang menegaskan, "wartawan dilarang menyiarkan berita yang tidak berdasarkan fakta atau memutarbalikan data dan fakta yang dapat menguntungkan atau merugikan pihak tertentu" (Rep: Fergi Nadira/ Red: Israr Itah dari Republika Online diposting pada hari Minggu, 21 Januari 2018 19:55 WIB). Penegasan tersebut menunjukan bahwa pembuatan 
Lisna Novita

dan penyiaran berita yang tidak akurat, tidak berimbang dan dengan itikad buruk bertentangan diametral dengan Kode Etik Jurnalistik.

"Kami memeringatkan dengan keras, pers dilarang keras membuat berita

bohong atau hoaks, berita yang mengandung pembunuhan karakter dan

ujaran kebencian. Pembuatan atau penyiaran berita bohong atau boaks,

berita yang sengaja dirancang untuk pembunuhan karakter serta berita ujaran kebencian merupakan penghianatan terhadap profesi wartawan,"

(Rep: Fergi Nadira/ Red: Israr Itah dari Republika Online diposting pada hari Minggu, 21 Januari 2018 19:55 WIB).

Independensi juga diperkuat oleh kajian Bill Kovach dan Tom Rosenstiel dalam bukunya yang berjdul Sembilan Elemen Jurnalisme (2001: 6) yang menempatkan independensi sebagai prinsip atau elemen keempat jurnalisme. Terdapat sembilan elemen jurnalisme, pada elemen keempat disebutkan, jurnalis harus tetap independen dari pihak yang mereka liput, "kewajiban utama jurnalisme adalah pencarian kebenaran dan jurnalis harus menjaga independensi dari objek liputannya bisa dikatakan bahwa seorang wartawan harus benar-benar bisa objektif dan independen. Kode Etik Jurnalistik baru yang dikukuhkan oleh Dewan Pers pada tanggal 14 Maret 2006 yang menegaskan dalam pasal 1: "Wartawan Indenesia bersikap independen...." yaitu memberitakan peristiwa atau fakta sesuai dengan suara hati nurani tanpa campur tangan, paksaan, dan intervensi dari pihak lain termasuk pemilik perusahaan pers.

Berita keislaman termasuk salah satu konten yang dimuat di setiap media pemberitaan yang juga membutuhkan indepedensi wartawan dalam pemberitaannya. Dewan Kehormatan PWI Pusat juga mengingatkan kepada seluruh pengurus PWI dilarang merangkap menjadi pengurus partai politik beserta seluruh lembaga yang terafiliasi dengan partai politik, beliau mengatakan "PWI pusat menyarankan agar wartawan memegang teguh untuk mengabdi kepada kepentingan umum dan kebenaran, bukan untuk kepentingan sekelompok atau segelintir golongan". Dengan demikian, pemahaman wartawan terhadap independensi wartawan akan menunjang sikap wartawan di lapangan pada saat proses pembuatan berita.

Kebebasan pers sangat penting dalam dunia jurnalistik, akan tetapi kebebasan tersebut akan lebih bermakna jika disertai dengan tanggung jawab, artinya bahwa, insan pers tidak menjadi bebas sebebas-bebasnya dalam berkreasi, tetapi kebebasan itu harus bisa dipertanggungjawabkan, atau yang lebih dikenal dengan istilah kebebasan yang bertanggung jawab. Terminilogi wartawan merupakan konsep penting yang perlu dipahami secara filosofis dalam internal seorang wartawan. Apabila tugas dan fungsi wartawan tidak difungsikan secara baik maka wartawan tersebut telah kelauar dari independensi wartawan. Berikut ini penjelasan salah seorang anggota PWI Jawa Barat:

Profesi wartawan sangatlah penting, karena kalau kita ikut ungkapan lama 
Independensi Wartawan PWI Jawa Barat dalam Berita Keislaman

bahwa wartawan adalah pilar demokrasi. Memang faktanya wartawan adalah salah satuorang yang memiliki kapasaitas untuk menulis berita/ informasi untuk kepentingan masyarakat. Kapasitas itu sangat spesial, hari ini memang banyak sekali orang-orang yang dengan mudah membuat berita, apalagi sekarang terdapat aplikasi media sosial yang memudahkan masyarakat biasa membuat dan mempublish sebuah berita/ informasi. Tanpa kaidah jurnalistik bisa berjalan dengan baik dalam membuat sebuah berita (Hasil wawancara dengan Wartawan/Reporter Republika, cetak dan online Rubrik Islam - Daerah Kab. Bandung, Bandung Barat, Cimahi, Kota Bandung bapak Muhammad Fauzi Ridwan, di kantor DPRD Kota Cimahi pada Hari Senin 23 April 2018 pukul 14.15 WIB).

Pendapat Muhammad Fauzi Ridawan tentang wartawan ini menunjukan bahwa independensi wartawan yang menghasilkan sebuh berita dapat menajdi acuan pemberitaan secara resmi. Independensi terdapat dalam Kode Etik Jurnalistik, pasal 1. Bapak Mirza Zulhadi menjelaskan tentang independensi berdasarkan kode etik jurnalistik sebagaimana berikut:

Yang bunyinya kurang lebih wartawan harus bersikap independen, membuat berita akurat, berimbang dan tidak beritikad buruk. Misal ketika Saya sebagai seorang wartawan akan mewawancarai Lisna, dalam frame saya harus bersih dulu terhadap Lisna, jangan tiba-tiba saya sudah punya frame sejak awal bahwa dalam fikiran saya Lisna itu sudah salah. Harus mengecek atau memverifikasi peristiwa secara benar dan berkelanjutan, jangan sampai hanya langsung menerima saja, tetapi memang harus benarbenar mengecek ulang akan kebenaran akan suatu peristiwa. (Hasil wawancara dengan Ketua PWI Jawa Barat bapak Mirza Zulhadi, di sekretariat PWI JAwa Barat pada Hari Rabu, 21 Febuari 2018 pukul 16.00 WIB).

Jurnalistik sebagai disiplin ilmu tidak dapat dilepaskan dari aktivitas komunikasi. Saat ini, jurnalistik dipandang sebagai suatu elemen yang memiliki kekuatan komunikasi. Perubahan peradaban manusia dan dinamika masyarakat sekaligus menjadi objek penting jurnalistik dan komunikasi. Hampir semua sisi kehidupan manusia dapat menjadi objek informasi, mulai dari yang bersifat privacy hingga yang bersifat massive (Yunus, 2010: 1-3).

Rahayu (2006: 1) mengungkapkan bahwa konsep independensi sangat mempengaruhi profesionalisme lapangan. Namun pada kenyataannya terdapat berbagai macam pelanggaran, diantaranya aalah kasus tentang fenomena wartawan amplop adalah yang terjadi di Kota Palu, fenomena tersbut terjadi karena faktor situasional, dalam setiap liputan kegiatan konfrensi pers atau seremonial yang dilakukan (Monika, 2017: 55). Prisgunanto (2017: 185) Menunjukan bahwa korelasi antara pemahaman kode etik wartawan dengan prpfesionalisme diapangan terbukti lemah. Contoh kasus kesaahan penuangan 
Lisna Novita

fakta dan data adalah pada acara Indonesia Lawyers Club (ILC) yang terbukti belum memenuhi (P3/SPS) Karena konten acara dan dialognya masih terkesan memihak dan belum berimbang dalam menyajikan fakta dan berita (Hidayati, 2015: 137).

Sejumlah organisasi profesi wartawan di Indonesia telah mengeluarkan Kode Etik Jurnalistik. Salah satu poin penting itu adalah masalah wartawan yang berkaitan dengan penerimaan imbalan atau amplop. Pada pasal 6 Kode Etik Jurnalistik yang dikeluarkan oleh Dewan Pers menyebutkan bahwa "Wartawan Indonesia tidak menyalahgunakan profesi dan tidak menerima suap" dalam poin A menyebutkan bahwa menyalahgunakan profesi adalah segala tindakan yang mengambil keuntungan pribadi atas informasi yang diperoleh saat bertugas sebelum informasi tersebut menjadi pengetahuan umum, serta dalam poin $\mathrm{B}$ menyebutkan suap adalah segala pemberian dalam bentuk uang,benda atau fasilitas dari pihak lain yang mempengaruhi independensi seorang wartawan”.

Dan hal-hal tersebut didalam organisasi PWI Jawa Barat sendiri selalu diingatkan kepada para anggora wartawan. Dan tidak hanya diingatkan, wartawan yang tergabung di dalam organisasi PWI Jawa Barat juga selalu mendapatkan pelatihan-pelatihan terkait dengan bagaimana seharusnya aktivitas wartawan ketika terjun ke lapangan untuk melakukan aktivitas jurnalistik (Hasil wawancara dengan Ketua PWI Jawa Barat bapak Mirza Zulhadi, di sekretariat PWI JAwa Barat pada Hari Rabu, 21 Febuari 2018 pukul 16.45 WIB).

Pelaksanaan Kode Etik Jurnalistik juga merupakan perintah dari UndangUndang Pasal 7 ayat 2 undang-undang No.40 tahun 1999 tentang pers yang berbunyi, "wartawan memiliki dan mentaati kode etik jurnalistik". Ini berarti, wartawan yang melanggar Kode Etik Jurnalistik sekaligus melanggar UndangUndang. Kode etik tersebut dibuat khusus dari, dan untuk wartawan itu sendiri dengan tujuan untuk menjaga martabat dan kehormatan profesi wartawan. Pada poin 5 Kode Etik Wartawan Indonesia juga menyebutkan bahwa "Wartawan Indonesia tidak menerima suap dan menyalahgunakan profesi dengan tidak menerima imbalan dalam bentuk apapun dari sumber berita, narasumber yang berkaitan dengan tugas-tuas kewartawanannya dan tidak menyalahgunakan profesi untuk kepentingan pribadi atau kelompok (Nurudin, 2009: 318).

Kebebasan pers bukanlah sesuatu yang sepele, karena dari situlah muncul terobosan besar dalam kehidupan bernegara dan berbangsa sesungguhnya menyoal kebebasan bersuara dan berpendapat dalam artian yang sesungguhnya.

Menerjemahkan independensi sebenarnya agak sulit juga, kalau dalam bahasa ideal jelas independensi berarti tidak berpihak, cover a both side, tidak bisa diintervensi, memberitakan berita secara berimbang, memberitakan berita sesuai dengan fakta, Tetapi kalau dalam realitas di lapangan kita harus pintar terlebih dahulu menafsirkan independensi mau 
Independensi Wartawan PWI Jawa Barat dalam Berita Keislaman

dibawa ke arah mana, misal Independensi dibawa ke wilayah Islam. Independensi Islam nya mau dibagian apa dulu, karena yang kita tahu sendirikan di dalam peta islam, terdapat ormas-ormas islam yang berbeda (Hasil wawancara dengan Wartawan Pikiran Rakyat Redaktur Rubrik Haji dan Ramdahan bapak H. Sarnafi, di kantor Pikiran Rakyat jl. Asia Afrika pada Hari Senin, 12 Maret 2018 pukul 18.10 WIB).

Pers yang bebas sebebas-bebasnya dalam mencari berita dan mewartakan sesuai apa yang dilihat dan dikajinya kepada masyarakat melalui sidang pembacanya juga bertanggungjawab adalah dambaan semua orang. Pers bukanlah "tukang kipas-kipas" atau pengadu domba dan keonaran di masyarakat. Melainkan menjadi pihak penengah, negosiator dan penyambung lidah rakyat dengan kejujuran dan kesadaran mereka akan arti profesionalisme kewartawanan.

Misal, otamatis nama wartawan harus merangkul semua, kalau misal saya orang yang sangat paham NU, atau muhamdiyah, tapikan saya sebagai wartawan ke ormas persis juga harus masuk, ke MA masuk ke ali irsyad masuk atau ke yang lainnya harus bisa masuk, itulah wartawan, ke ahmadiayah bila perlu, atau ke kalangan syiah.. dan selama ini alhamdulillah kalau saya memang diterima disemua ormas, kalau saya masuk NU saya dianggap orang NU, kalau saya masuk ke wilayah Muahamadiyah saya dianggap orang Muhamadiyah, begitupun ke tokohtokohnya, itu kalau menurut saya yang dinamakan independensi, itulah kiranya yang bisa saya jawab (Hasil wawancara dengan Wartawan Pikiran Rakyat Redaktur Rubrik Haji dan Ramdahan bapak H. Sarnafi, di kantor Pikiran Rakyat jl. Asia Afrika pada Hari Senin, 12 Maret 2018 pukul 18.35 WIB).

Di pembukaan kode etik jurnalistik telah dinyatakan kebebasan pers adalah perwujudan kemerdekaan menyatakan pendapat sebagaimana tercantum dalam Pasal 28 UUD 1945, yang sekaligus pula merupakan salah satu ciri negara hukum. Namun kemerdekaan/kebebasan tersebut adalah kebebasan yang bertanggung jawab dan semestinya sejalan dengan kesejahteraan sosial yang dijiwai oleh landasan moral. Karena itu PWI menetapkan Kode Etik Jurnalistik yang salah satu landasannya adalah untuk melestarikan kemerdekaan/kebebasan pers yang bertanggung jawab, di samping merupakan landasan etika para jurnalis. Satu yang diketahui bahwa di masa kebebasan dan keterbukaan informasi saat ini, seolah-olah pers melupakan kode etik jurnalistik mereka sendiri. Padahal jelas etika jurnalistik berfungsi agar wartawan tidak terjebak dalam perangkap aturan hukum yang menyoal delik pers. Kode etik dibentuk oleh lembaga profesi dan asosiasi dalam keperluan memberikan arahan dan batasan yang jelas terhadap profesi dan kerja insan pers.

Saya hanya berusaha untuk terus menjadi wartawan yang independen, 
terus menjadi profesional dengan menerapkan etika hukum yang berlaku di dunia jurnalistik (Hasil wawancara dengan Wartawan Pikiran Rakyat Redaktur Rubrik Haji dan Ramdahan bapak H. Sarnafi, di kantor Pikiran Rakyat jl. Asia Afrika pada Hari Senin, 12 Maret 2018 pukul 18.50 WIB).

Menurut Tebba (2005: 136), dalam menjalankan tugasnya wartawan selain dibatasi ketentuan hukum seperti UU Pers nomor 40 tahun 1999, juga harus berpegang kepada kode etik jurnalistik. Tujuannya adalah supaya wartawan bertanggung jawab dalam menjalankan profesi. Etika yang berarti aturan atau kaidah-kaidah moral, tata susila yang mengikat suatu masyarakat atau kelompok masyarakat, atau profesi. Etika didasari oleh kejujuran dan integritas perorangan. Etika yang mengikat masyarakat dalam sebuah profesi itulah yang disebut Kode Etik, maka lahirlah berbagai macam Kode Etik, antara lain Kode Etik Wartawan atau Kode Etik Jurnalistik, Kode Etik Kedokteran, dan Kode Etik Pengacara dan lain-lain. Di Indonesia, Kode Etik Wartawan tidak hanya merupakan ikatan kewajiban moral bagi anggotanya, melainkan sudah menjadi bagian dari hukum positif, karena Pasal 7 (2) UU Pers dengan tegas mengatakan bahwa wartawan memiliki dan menaati Kode Etik Jurnalistik. Kode Etik Jurnalistik dimaksud, yaitu kode etik yang disepakati organisasi wartawan dan ditetapkan oleh Dewan Pers.

Selama saya menjadi wartawan, saya tidak merasa sudah mencedaerai nilai independensi, kalau kita melihat kasus-kasus banyak diberitakan mengenai Islam radikal atau Islam teroris.. sebenarnya kita harus tahu terlebih dahulu, radikal itu apa, teroris itu apa. (Hasil wawancara dengan Wartawan Pikiran Rakyat Redaktur Rubrik Haji dan Ramdahan bapak H. Sarnafi, di kantor Pikiran Rakyat jl. Asia Afrika pada Hari Senin, 12 Maret 2018 pukul 19.20 WIB)

Tugas pers yang profesional harus memenuhi hak masyarakat untuk mengetahui menegakkan nilai-nilai dasar demokrasi, mendorong terwujudnya supremasi hukum dan hak asasi manusia, serta menghormati kebhinekaan. Di samping itu, juga perlu mengembangkan pendapat umum berdasarkan informasi yang tepat, akurat dan terpercaya dalam melakukan pengawasan, kritik, koreksi, dan saran terhadap hal-hal yang berkaitan dengan kepentingan umum, memperjuangkan keadilan dan kebenaran kemerdekaan berpendapat, berekspresi, dan pers adalah hak asasi manusia yang dilindungi Pancasila, Undang-Undang Dasar 1945, dan Deklarasi Universal Hak Asasi Manusia PBB (Harymurti, 2011: 3).

Berbicara mengenai independensi sebenarnya akan sangat rumit, karena setiap orang akan berbeda penafsiran apabila sudah dilapangan. Jika berbicara secara normatif jelas independensi berarti tidak memihak, tidak memberitakan secara berat sebelah, harus berimbang. (Hasil wawancara dengan Ketua PWI Jawa Barat bapak Mirza Zulhadi, di sekretariat PWI 
JAwa Barat pada Hari Rabu, 21 Febuari 2018 pukul 17.00 WIB).

Berdasarkan pernyataan-pernyataan informan tersebut dapat disimpulkan bahwa PWI Jawa Barat sangat mengerti terhadap konsep independensi, namun masih terdapat fleksibilitas terhadap kepentingan pihak tertentu dengan catatan tidak akan merugikan pihak lainnya. Sebagai mana uangkapan terakhir dari ketua PWI Jawa Barat yang mengungkapkan tentang berita pesanan bahwa "selama itu tidak merugikan pihak manapun, maka media bisa saja memberitakannya". Dengan demikian konsep independensi perspektif PWI Jawa Barat boleh memberitakan peranan berita berdasarkan kepentingan pengiklan dengan catatan tidak akan merugikan pihak lain.

Hasil dari rangkaian analisis terhadap hasil wawancara dengan informan dapat dismpulkan bahwa pemahaman wartawan PWI Jawa Barat terhadap konsep independensi secara harfiyah sangat memahami makna independensi. Namun dari segi penafsiran makna independensi itu sendiri realitas di lapangan dapat berubah sesuai dengan situasi dan kondisi tertentu karena pada dasarnya media non pemerintah masih membutuhkan profit dari penedyia iklan. Berdasarkan hasil analisis terhadap ketiga informan yang telah dipilih menunjukan bahwa pemahaman wartawan PWI Jawa Barat terhadap konsep independensi sangat baik namun memandang konsep terebut sebuah landasan kerja ideal yang tertulis secara regulatif dan masih bersifat fleksibel dalam pelaksanaannya.

\section{Wartawan PWI Jawa Barat dalam Mengkonstruksi Suatu Realitas Menjadi Sebuah Berita}

Salah satu produk utama didalam media masa adalah berita, berita menempati posisi terdepan sebagai salah satu bagian dari produk informasi tentang segala hal yang sangat berguna dan bermanfaat dalam rangka memberikan pencerahan bagi peradaban kehidupan manusia kearah yang lebih baik. Realitas-realitas peristiwa yang terjadi dalam semua aspek kehidupan yang meliputi : aspek sosial, hukum, ekonomi, poitik, agama dll semuanya merupakan bahan-bahan utama proses terjadinya suatu berita yang akan disajikan pada masyarakat.

Para pemangku kepentingan dalam produk berita suatu media massa (Abdullah (2000) : Pemimipin Redaksi, Dewan Redaksi, Redaktur pelaksana, Sekretaris Redaksi, Staf Redaksi, Redaktur Desk hingga wartawan mempunyai peran penting bagaimana suatu berita dapat di ekpose dengan kadar kualitas jurnalisme yang baik. Diantara semua pemangku kepentingan diatas, peran ujung tombak terdepan dan strategis berada dalam pundak wartawan, karena wartawan adalah insan jurnalis yang pertama kali meliput suatu pemberitaan dilapangan, dalam peran inipulalah suatu kualitas berita dengan bobot baik sangat menentukan. Prinsip-prinsip jurnalisme yang senantiasa mengutamakan aspek Aktualitas, faktualitas, Impartialitas senantiasa menjadi rujukan utama semua wartawan selain itu pula rambu-rambu regulasi (UU Pers no 40 tahun 1999) 
Lisna Novita

maupun kode etik jurnalistik menjadi batasan gerak profesional para wartawan akan senantiasa dijadikan sebagai pegangan. Berikut ini pernyataan salah satu wartawan PWI tentang pandangannnya terhadap ralitas dalam sebuah pemberitaan:

Dari kejadian atau realitas itu sendiri, jika realitas itu akan dianggap sangat penting oleh masyarakat, maka saya akan menggang berita itu layak untuk diberitakan. Bisa saya lihat dari tokoh, dari korban, dari lokasi atau lainnya sesuai dengan kebutuhan saat itu. (Hasil wawancara dengan Wartawan/Reporter Republika, (cetak dan online) Rubrik Islam - Daerah Kab. Bandung, Bandung Barat, Cimahi, Kota Bandung bapak Muhammad Fauzi Ridwan, di kantor DPRD Kota Cimahi pada Hari Senin 25 Juni 2018 pukul 14.11 WIB)

Tentu realitas lapangan saat diberitakan akan memunculkan kotroversi atara pro dan kontra, namun dengan independensi dan kehatihatian wartawam dalam memberitakan berita sebagai mana telah diinstruksikan oleh PWI bahwa nilai independensi dalam sebuah berita sangatlah penting. Berikut ini pernyataan bapak H. Sarnafi tentang pengalamannya dalam membuat berita kesilaman dimulai dari pandangannya terhadap suatu realitas kemudian diangkat menjadi sebuah berita:

Selama saya membuat berita Islam, kalau di PR saya tidak pernah membuat berita yang berbau negatif. Kalau pun misal ada suatu peristiwa tentang FPI yang sudah merampas dan meruntuhkan warung warga yang menjual miras tapi berbentuk kekerasan, maka saya tidak secara gamblang menulis FPI, melainkan menggunakan kata "ormas", tidak disebutkan namanya, karena kalau disebut secara jelas kita bisa di demo. Misal "Sebuah Ormas Melakukan Kerusakan". Misal saat saya mau memberitakan mengenai aliran sesat, biasanya diawali dengan kata "Diduga.." ciri-ciri melaukan ibadat seperti ini, dengan tokohnya siapa saja.. akrena ada dasarnya kita tidak bisa menjudge itu aliran sesat atau tidak, yang menentukan sesat sebenarnya adalah MUI. (Hasil wawancara dengan Wartawan Pikiran Rakyat Redaktur Rubrik Haji dan Ramdahan bapak H. Sarnafi, di kantor Pikiran Rakyat jl. Asia Afrika pada Hari Rabu, 11 April 2018 pukul 19.35 WIB).

Proses konstruksi pemberitaan yang dilakukan oleh Pwartawan PWI Jawa Barat ini merupakan proses jurnalisme publik memberi kesempatan yang luas kepada masyarakat berdialog dan berdebat tentang segala hal yang mempengaruhi. kehidupannya (Rachmiatie \& Atie, 2006: 52). Pengalaman atau uangkapan yang diungkapkan oleh bapak H. Sarnafi tersebut sejalan dengan Stuart Hall dalam Ahmad Mulyana (2011) yang mempertegas bahwa realitas adalah tidaklah secara sederhana dapat dilihat sebagai satu set fakta, tetapi hasil dari ideologi atau pandangan tertentu. Berikut ini pernyataan salah satu anggota 
PWI Jawa Barat tentang kendala dalam memberitakan pemberitaan keislaman:

Tidak ada, tetapi kalau saya memberitakan Islam dalam ranah politik memang agak sedikit harus hati-hati juga. Keberpihakan umat Islam dalam ranah politik, ormas Islam, caleg-valeg yang Islami, karena Islam memangmengatur semua, termasuk dalam ranah politik, ataukah hanya berkedok agama saja, kita yang harus bisa membedakan. Pernah ada yang komplain, misalnya seperti yang tadi memberitakan aliran sesat, itu kan sangat sensitif. (Hasil wawancara dengan Wartawan Pikiran Rakyat Redaktur Rubrik Haji dan Ramdahan bapak H. Sarnafi, di kantor Pikiran Rakyat jl. Asia Afrika pada Hari Rabu, 11 April 2018 pukul 19.55 WIB)

Bukan merupakan ketidaksengajaan suatu realitas dalam berita dikonstruksi menjadi realitas media, karena memang media berita itu sendiri sebenarnya adalah tempat "pertarungan kekuatan ideologi berbagai pihak yang berkepentingan". Pertarungan kekuatan yang berinteraksi terhadap manajemen media yang pada akhirnya akan menentukan isi (content) yang ditampilan oleh media, Morissan (2000) membagi tujuh pihak kekuatan yang mempengaruhi proses jurnalistik media 1) Penguasa/pemerintah, 2) Masyarakat umum, 3) Kelompok penekan, 4) Pemilik, 5) Pemasang iklan, 6) Audiens, dan 7) Internal organisasi. Dalam hal ini, apabila wartawan tidak memgang teguh terhadap independensi waratan maka dalam konsep islam akan terjadi pertukaran antara yang haq dan bathil. Berikut ini pernyataan wartawan PWI Jawa Barat tentang pesanan berita:

Kalau tentang ulama dengan posisi salah dan memesan pencitraan mah sampe saat ini tidak pernah, tetapi kalau yang memesan pernyataan memang selalu ada saja. Tetapi kan itu harus imbang, berita harus cover a both side, atau kalau dalam bahasa arabnya ahrus tabayyun, misal pernyataan MUI seperti ini, pernyataan saya seperti ini, nanti tinggal masyarakat/ kaum muslimin aja yang menilai faktanya kemana. Jadi bukan ini beritanya ahrus begini, tidak. Tergantung kitanya saja. (Hasil wawancara dengan Wartawan Pikiran Rakyat Redaktur Rubrik Haji dan Ramdahan bapak H. Sarnafi, di kantor Pikiran Rakyat jl. Asia Afrika pada Hari Rabu, 11 April 2018 pukul 20.16 WIB)

Kekuatan-kekuatan inilah yang senantiasa memberikan pengaruh yang cukup signifikan dalam konstruksi suatu berita, selintas suatu berita yang sampai pada masyarakat, adalah berita-berita yang senantiasa berdasarkan pada kaidah prinsip-prinsip jurnalisme, akan tetapi sebenarnya kekuatan-kekuatan dominan inilah yang bermain. Konstruksi realitas yang dilakukan media tentunya akan membawa pengaruh yang menentukan dalam pembentukan pengetahuan, kepercayaan, nilai, relasi sosial, identitas sosial yang ada pada masyarakat. Karena walau bagaimanapun juga media mempunyai kekuatan yang cukup menentukan dalam kehidupan sosial masyarakat. 
Dan biasanya juga kita tidak terlalu jauh dalam memberitakan berita Islam, apalagi PR juga sesungguhnya bukan media yang sangat khusus memberitakan berita-berita tentang keislaman, beda dengan media misalnya Republika yang memang beprinsip merupakan media Islam, kalau PR memang tidak terlalu mendalam. (Hasil wawancara dengan Wartawan Pikiran Rakyat Redaktur Rubrik Haji dan Ramdahan bapak H. Sarnafi, di kantor Pikiran Rakyat jl. Asia Afrika pada Hari Rabu, 11 April 2018 pukul 20.33 WIB).

Dari semua itu, layak kita pertimbangkan apabila kita merujuk pada pandangan Dede Mulkan (2011) : Sebuah peristiwa atau kejadian yang memiliki nilai berita sangat tinggi tidak serta merta layak diangkat menjadi berita, jika dilihat dari sisi pertimbangan berita (news judgment), bakal menimbulkan dampak yang tidak diharapkan. Tentunya yang kita harapkan adalah pemberitaan media yang profesional yang senantiasa memberikan pencerahan peradaban dalam sendi-sendi kehidupan manusia secara positif. Yang bertugas menulis rubrik haji dan ramadhan di Pikiran Rakyat ini menambahkan tentang cara mengkonstruksi sebuah realitas menjadi berita yang menarik untuk dibaca:

Kan wartawan yang sudang lama dilapangan biasanya sudah punya sense of news, misal, untuk mmebuat berita kan ada $5 \mathrm{~W}+1 \mathrm{H}$, ah misal ternyata What nya kurang menarik, kita bisa pindah ke Where dan seterusnya. (Hasil wawancara dengan Wartawan Pikiran Rakyat Redaktur Rubrik Haji dan Ramdahan bapak H. Sarnafi, di kantor Pikiran Rakyat jl. Asia Afrika pada Hari Rabu, 11 April 2018 pukul 20.45 WIB).

Berita ke-Islaman adalah informasi/peristiwa apa saja yang memuat konten tentang Islam dan menarik perhatian orang. Berita ke-Islaman memuat dan memfokuskan isi peristiwa yang bersifat khas. Misalnya pemberitaan mengenai tokoh agama Islam, sejarah agama Islam, organisasi Islam, aksi damai yang mengatasnamakan Islam, teroris yang dikaitkan dengan agama Islam, dan lain sebagainya. Melihat berita di dalam dunia jurnalistik, berita tidaklah hadir dengan sendirinya. Berbagai berita yang setiap hari dapat dipublikasian melalui media massa merupakan hasil karya wartawan yang ditulis setelah melakukan liputan,

Secara umum, berita merupakan laporan mengenai peristiwa yang ada di masyarakat dan sekitarnya yang disampaikan melalui media massa. Ermanto (2005: 78) dalam bukunya mengatakan bahwa sebagai mahluk sosial, manusia akan selalu membutuhkan media atau informasi untuk menambah wawasannya dan mendewasakan alam berpikirnya. M. Atar Seni (1995: 11) menyatakan bahwa berita adalah cerita atau laporan mengenai kejadian atau peristiwa yang faktual yang baru dan luar biasa sifatnya. Sementara J.B. Wahyudi (Djuroto, 2004:47) memberikan definisi tentang berita yakni sebagai laporan tentang peristiwa atau pendapat yang memiliki nilai yang penting dan menarik bagi sebagian khalayak, 
Independensi Wartawan PWI Jawa Barat dalam Berita Keislaman bersifat baru dan dipublikasikan secara luas melalui media massa. Peristiwa atau pendapat tidak akan menjadi berita, bila tidak dipublikasikan media massa secara periodik.

Kehatihatian dalam pembertitaan rubrik-rubrik Islam, semua informan yang diwawancarai menyatakan bahwa dalam pemberitaannya memerlukan pemilihan diksi yang sesuai. Ketingga informan termasuk ketua PWI Jawa Barat mengungkapkan bahwa dalam memberitakan berita-berita keislaman harus sangat hati-hati. Bahkan mereka semua menyatakan bahwa apabila berita keislaman yang telah dibuat sekiranya terdapat unsur kontradiktif maka mereka lebih memilih unutk tidak memuat berita tersebut. Pada dasarnya realitas atau peristiwa di lapangan harus sama persis terbertitakan, diawali dengan konsep independensi yang dapat membuat pers menjadi netral. Kemampuan wartawan dalam mengemas sebuah berita tentu tidak bisa didapatkan secara instan melainkan perlu pengalaman yang banyak dalam menulis berita.

\section{PENUTUP}

Pemahaman wartawan PWI Jawa Barat terhadap konsep independensi sangat baik namun memandang konsep terebut sebuah landasan kerja ideal yang tertulis secara regulatif dan masih bersifat fleksibel dalam pelaksanaannya. Konstruksi realitas yang dilakukan PWI Jawa Barat tidak jauh bebeda dengan para wartawan pada umunya yang mengkonstuksi realitas yang berlandaskan kepentingan pengiklan dengan catatan tidak akan menimbulkan keresahan kepada pihak mana pun. Interpretasi berita keislaman yang dilakukan pun dilakukan dengan baik namun sangat hati-hati dalam memilih kata dan memuat kalimat. Maka PWI Jawa Barat sagat mengerti dan memandang penting konsep independensi, namun konsep tersebut bersifat fleksibel saat proses konstruksi pemberitaan di lapangan khusnya pada berita keislaman, karena konstruksi pemberitaan yang dilakukan oleh wartawan PWI Jawa Barat masih dilakukan berdasarkan kepentingan pemilik media.

Wartawan PWI Jawa Barat melakukan konstruksi terhadap sebuah berita secara objektif sehingga realitas atau peristiwa yang ada dilapangan objektif suatu peristiwa akan menjadi realitas media pemberitaan yang baik untuk dikonsumsi khalayak. Realitas peristiwa di lapangan dibangun unsur penambahan atau pengurangan berbasarkan kepentingan tertentu, dalam konteks tersebut terdapat suatu makna dibalik realitas. Konteks tersebut terdapat suatu makna dibalik realitas, dalam mengkonstruksi realitas menjadi sebuah berita wartawan PWI Jawa Barat tidak jauh bebeda dengan para wartawan pada pumunya yang mengkonstuksi realitas kedalam sebuah berita berdasarkan fakta dan data yang jelas namun wartawan PWI Jawa Barat masih memiliki fleksibilitas untuk menerima pesanan pemberitaan dengan catatan tidak berita tersebut tidak akan menyebabkan konfilk tertentu dari pihak mana pun. 
Lisna Novita

Pada tataran dilapangan, wartawan PWI Jawa Barat melakukan konstruksi terhadap sebuah berita secara objektif sehingga realitas objektif suatu peristiwa akan menjadi realitas media yang baik untuk dikonsumsi khalayak. Realitas peristiwa dilapangan dibangun unsur penambahan atau pengurangan berdasarkan kepentingan tertentu, dalam konteks tersebut terdapat suatu makna dibalik realitas, dalam mengkonstruksi realitas menjadi sebuah berita wartawan PWI Jawa Barat tidak jauh bebeda dengan para wartawan pada umunya yang mengkonstuksi realitas yang berlandaskan kepentingan pengiklan dengan catatan tidak akan menimbulkan keresahan kepada pihak mana pun.

Kemerdekaan pers memang merupakan sarana masyarakat untuk memperoleh informasi dan berkomunikasi, guna memenuhi kebutuhan hakiki dan meningkatkan kualitas kehidupan manusia. Dalam mewujudkan kemerdekaan pers itu, wartawan Indonesia juga perlu menyadari adanya kepentingan bangsa, tanggung jawab sosial, keberagaman masyarakat, dan norma-norma agama.

Dalam melaksanakan fungsi, hak, kewajiban dan peranannya, pers menghormati hak asasi setiap orang, karena itu pers dituntut profesional dan terbuka untuk dikontrol oleh masyarakat. Untuk menjamin kemerdekaan pers dan memenuhi hak publik untuk memperoleh informasi yang benar, wartawan Indonesia memerlukan landasan moral dan etika profesi sebagai pedoman operasional dalam menjaga kepercayaan publik dan menegakkan integritas serta profesionalisme. Atas dasar itulah, maka wartawan Indonesia harus menetapkan dan menaati Kode Etik Jurnalistik.

Berdakwah melalui surat kabar erat kaitannya dengan tiga komponen yang akan mempengaruhi berhasilnya media surat kabar yaitu pemilik modal, pemimpin redaksi, dan wartawan yang harus berjalan seiring agar dakwah tetap eksis melalui surat kabar. Berita Islam adalah berita yang bisa memberi tahu ajaran-ajaran tentang Islam, memberitakan kiprah tokoh-tokoh dalam Islam, pernyataan-pernyataan setiap tokoh, atau memberitakan kiprah ormasnya, memberitakan lembaga pendidikan Islam, memberitakan masalah di masyarakat, itu semua bisa menjadi beita.

Realitas atau peristiwa di lapangan pada dasarnya harus sama persis terbertitakan, diawali dengan konsep independensi yang dapat membuat pers menjadi netral. Kemampuan wartawan dalam mengemas sebuah berita tentu tidak bisa didapatkan secara instan melainkan perlu pengalaman yang banyak dalam menulis berita.

Wartawan PWI Jawa Barat sangat berhati-hati dalam pembertitaan rubrikrubrik Islam, dalam pemberitaannya memerlukan pemilihan diksi yang sesuai, dalam memberitakan berita-berita keislaman harus sangat hati-hati. Apabila berita keislaman yang telah dibuat sekiranya terdapat unsur kontradiktif maka mereka lebih memilih untuk tidak memuat berita tersebut. Realitas atau peristiwa 
Independensi Wartawan PWI Jawa Barat dalam Berita Keislaman

di lapangan pada dasarnya harus sama persis terbertitakan, diawali dengan konsep independensi yang dapat membuat pers menjadi netral. Kemampuan wartawan dalam mengemas sebuah berita tentu tidak bisa didapatkan secara instan melainkan perlu pengalaman yang banyak dalam menulis berita.

Berdasarkan kesimpulan penelitian tersebut, maka penelitian ini memberikan saran kepada akademisi/ peneliti selanjutnya, penelitian ini dapat menjadi sumber rujukan bahkan menjadi pedoman tentang kerangka untuk merancang penelitian tentang independensi pemberitaan. Dalam penelitian ini hanya membahas tentang aspek pemberitaan Islam, maka sangat disarankan kepada peneliti selanjutnya apabila akan mengkaji tentang independensi di organisasi Persatuan Wartawan Indonesia sangat dianjurkan untuk mengkaji independensi pada aspek lain seperti pemberitaan politik, ekonomi dan sosial.

\section{DAFTAR PUSTAKA}

Assegaf, D. (1991). Jurnalistik Masa Kini. Jakarta: Ghalia Indonesia.

Berutu, D.I. (2012). Analisis Foto Jurnalistik mengenai Kerusuhan di Mesuji Lampung pada Harian Kompas, dalam Jurnal Flow, 1(1).

Dahlan, A.C. (2011). Hukum, Profesi Jurnalistik dan Etika Media Massa, dalam Jurnal Hukum, 25(1), 395-411.

Darmanto. (2015). Urgensi Perubahan Kebijakan untuk Penegakkan Independensi Media di Indonesia. Jurnal Komunikasi, 10(1), 29-39.

Djuroto, T. (2004), Manajemen Penerbitan Pers, Bandung: Remaja Rosdakarya

Dulwahab, E. (2010). Dakwah di Era Konvergensi Media. Ilmu Dakwab: Academic Journal for Homiletic Studies, 5(16), 23.

Ermanto. (2005). Menjadi Wartawan Handal \& Profesional. Yogyakarta : Cinta. Pena. Djuroto,

Haryoputro, A. T. (2015). Pemilihan Presiden Dan Wakil Presiden Di Media Online (Konstruksi Pemberitaan Media Online Sindonews.com dalam Pengumuman Hasil Pemilu Capres dan Cawapres 2014 Tanggal 22 Juli 2014 Sampai Tanggal 21 Agustus 2014). Thesis, Universitas Mubammadiyah Surakarta.

Heryanto, G. (2017). Ekonomi Politik Media Penyiaran: Rivalitas Idealisme Nilai

Islami dan Mekanisme Pasar, dalam Jurnal Communicatus: Jurnal Ilmu Komunikasi, 1(1), 85-98.

Hidayati, L. T. (2015). Persepsi Jurnalis Surat Kabar Harian Kaltim Post Mengenai Implementasi Pedoman Perilaku Penyiaran (P3) Dan Standar Program Siaran (SPS) Pada Acara Indonesia Lanyers Club di TVONE. dalam Ejournal Ilmu Komunikasi, 3(2) 137-149.

Kovach, B. \& Rosenstiel, T. (2001). Sembilan Elemen Jurnalisme. Jakarta: Yayasan Pantau.

Kusumaningrat, H. \& Purnama. (2005). Jurnalistik Teori dan Praktik. Bandung : 
Lisna Novita

PT.Remaja. Rosdakarya,

Monika, R. (2017). Fenomena Wartawan Amplop Di Kota Palu (Studi Kasus

Pada Wartawan Aji). Dalam Jurnal Online Kinesik: Program Studi Ilmu Komunikasi FISIP Universitas Tadulako, 2(4), 55-67.

Mujianto, G. (2018). Analisis Wacana Kritis Pemberitaan tentang Ormas Islam pada Situs Berita Online. Dalam Jurnal Kembara, 4(2), 155-172.

Mulyana, D. (2008). Komunikasi efektif "Suatu pendekatan lintas budaya". Bandung :

PT Remaja Rosdakarya.

Musfialdi (2019). Independensi Media: Pro-Kontra Objektivitas dan Netralitas Pemberitaan Media. dalam Jurnal Riset Komunikasi, 2(1), 21-28.

Nasriah, S. T. Surat Kabar Sebagai Media Dakwah. dalam Jurnal Dakwah Tabligh: Fakultas Dakwah dan Komunikasi UIN Alauddin Makassar, 1(13) 161-176.

Nurudin. (2009). Pengantar Komunikasi Massa. Jakarta: PT Raja Grafindo Persada.

Prisgunanto, I. (2017). Kode Etik Jurnalistik Di Kalangan Wartawan Media

Massa Cetak Islam. dalam Jurnal Komunikasi Global: Sekolah Tinggi Ilmu Kepolisian, 2(6), 185-199.

Rachmiatie, Y. Y. \& Atie. (2006). Komitmen Wartawan Terhadap Jurnalistik

Publik. dalam mimbar: Fakultas Ilmu Komunikasi UNISB A, 1(12), 52-92.

Rahayu, T. (2006). Pengaruh Independensi Auditor, Etika Auditor, Dan

Pengalaman Auditor Terhadap Kualitas Audit. dalam Jurnal Ilmu dan Riset

Akuntansi : Sekolab Tinggi Ilmu Ekonomi Indonesia (STIESLA) Surabaya, 4(5), 1-16.

Sulistyowati, F. (2006). Organisasi Profesi Jurnalis dan Kode Etik Jurnalistik, dalam Jurnal Ilmu Komunikasi, 3(2), 119-129.

Sumadiria, A. S. H. (2005). Jurnalistik Indonesia. Menulis Berita dan Feature. Panduan Praktis Jurnalis Profesional. Bandung: PT. Remaja Rosdakarya.

Tatipang, R.A. (2013). Fenomena Pelanggaran Kode Etik Jurnalistik Pasal 12

Tahun 2008 di Media Online Manado Post, dalam Jurnal Acta Diurna, 2(4).

Wibawa, D. (2012). Meraih Profesionalisme Wartawan. Bandung: UNISBA

Yunus, S. (2010). Jurnalistik terapan. Bogor: Ghalia Indonesia 